Jurnal Syntax Imperatif: Jurnal Ilmu Sosial dan Pendidikan

p-ISSN: 2721-2491 e-ISSN: 2721-2246

Vol. 2, No. 1, Maret 2021

\title{
Perbandingan Pemikiran Ahmad Tafsir dengan Paulo Freire Mengenai Filsafat dan Ilmu Pendidikan
}

\author{
Nurdin Abdul Aziz \\ Program Studi Pendidikan Agama Islam, Sekolah Tinggi Agama Islam (STAI) Persis \\ Bandung, Indonesia \\ ndin.alfatan15@gmail.com
}

\begin{abstract}
Absrak
Pendidikan merupakan panggilan ontologis manusia. Seseorang dari mulai berjalan, hingga dapat berbahasa, tak lepas dari pendidikan. Seiring berjalannya waktu, pendidikan disistematiskan, lalu mengkonsep dan merumuskan filsafat serta ilmu pendidikan. Dalam mengkonsep dan merumuskan filsafat serta ilmu pendidikan itulah terdapat perbedaan pendapat, hingga membentuk berbagai aliran dan ideologi. Ahmad Tafsir mengambil agama Islam sebagai dasar pemikirannya, sedang Paulo Freire mengambil pendidikan kritis. Tujuan penelitian ini adalah untuk mengetahui pamikiran Ahmad Tafsir dan Paulo Freire mengenai filsafat dan ilmu pendidikan. Aspek yang diambil dari filsafat dan ilmu pendidikannya adalah hakikat manusia, dasar pendidikan, tujuan pendidikan dan metode pendidikan. Lalu dibandingkan untuk mengetahui persamaan dan perbedaannya. Masing-masing aspek yang dibahas, mempunyai titik kesamaan dan perbedaan. Secara universal, persamaannya adalah memandang pendidikan bukan sekedar belajar angka dan teori, tetapi juga belajar tentang kehidupan. Maka, sebaik-baiknya pendidikan adalah yang mampu mengatasi jamannya. Perbedaannya terletak pada asumsi. Ahmad Tafsir mendasarkan pendidikannya pada ajaran agama Islam, sedang Paulo Freire mendasarkannya pada akal dan norma-norma kemanusiaan. Perbedaan asumsi itu dipacu oleh perbedaan lingkungan dan realitas sosial yang mereka hadapi.
\end{abstract}

Kata kunci: Pendidikan Islam; Pendidikan Kritis; Filsafat Ilmu;

\section{Pendahuluan}

Tanpa harus menggunakan bahasa pendidikan, sebenarnya setiap manusia sudah melakukan aktifitas mendidik. Anak yang baru lahir, mulai belajar merangkak, berjalan, hingga orang tuanya mengenalkan nama benda-benda. Setelah cukup umur, anak-anak diajarkan membaca, berhitung, hingga mengenali dunia sekelilingnya.

Setelah pendidikan disistematiskan dan membentuk sebuah lembaga, orang tua si anak merasa belum cukup bila hanya mendidik dengan caranya sendiri. Dengan suka rela orang tua si anak pun memasukkan anaknya pada sebuah lembaga pendidikan, berharap si anak mendapat keterampilan dan pengetahuan yang lebih. Wajah lembaga pendidikan pun terasa amat diperlukan untuk membantu membimbing ahlak dan mengejar cita-cita selangit si anak.

Wujud adanya sebuah lembaga pendidikan tak lepas dari namanya visi-misi. Lembaga pendidikan merupakan kepanjangan tangan dari filsafat dan ilmu pendidikan itu sendiri. Lembaga pendidikan seakan sudah tak terpisahkan dari eksistensi pendidikan yang berpacu pada panggilan ontologis manusia. Barang tentu, lembaga pendidikan meramu dan meracik agar pendidikan yang berjalan sesuai dengan cita-citanya dan tidak 
kehilangan esensi. Dalam meramu dan meracik eksistensi pendidikan inilah yang selalu terdapat perbedaan pendapat, bahkan ada yang bertentangan satu sama lainnya.

Ahmad Tafsir, yang bernapaskan pada pendidikan Islam mengatakan, bahwa pendidikan harus mampu mendidik manusia menjadi manusia yang utuh, atau dalam bahasa Arab adalah insanul kamil. Tujuan pendidikan adalah meningkatkan derajat kemanusiaan manusia (Ahmad, 2012, p. 46)

Bagi Ahmad Tafsir, tugas pendidikan, termasuk pendidikan di sekolah, yang paling utama adalah menanamkan nilai-nilai. Dalam garis besarnya nilai hanya ada tiga macam, yaitu nilai benar-salah, nilai baik-buruk, dan nilai indah-tidak indah. Nilai benar-salah digunakan dalam ilmu sains, semua filsafat, kecuali etika mazhab tertentu. Nilai baikburuk digunakan hanya dalam etika. Adapun nilai indah-tidak indah digunakan untuk menetapkan nilai seni. Nilai-nilai dalam agama pun, sebagaian masuk pada nilai benarsalah, sebagian pada nilai baik-buruk, dan sebagaiannya lagi pada nilai indah-tidak indah

Selanjutnya Ahmad Tafsir menuturkan ada tiga aspek yang mesti dijaga dalam ilmu pendidikan islam, yaitu aspek jasmani, aspek akal dan aspek hati (Ahmad, 2012, p. 33). Ketiga aspek itu harus dikelola secara seimbang, jangan sampai ada yang tidak terkelola, karena hal itu akan menimbulkan ketimpangan pada diri manusia, sebagai pendidik juga peserta didik.

Sedangkan bagi Paulo Freire yang selalu berorientasikan pada humanisasi, berpendapat bahwa pendidikan harus mengarah pada pembebasan manusia, karena humanisasi dan dehumnisasi merupakan alternatif yang real yang harus dipilih salah satunya. Baginya, pembebasan yang sejati terjadi ketika yang awalnya tangan-tangan terangkat untuk mengemis, diubah menjadi tangan-tangan terangkat untuk mengubah dunia (Freire, 2018, p. 19)

Filsafat pendidikan Paulo Freire mengatakan bahwa pembebasan menjadi hakikat dan tujuan, karena itu, fitrah manusia adalah menjadi merdeka. Maka anak didik pun tak lagi dijadikan objek oleh gurunya, tetapi sama-sama subjek yang bebas dan sadar akan posisinya di dunia, sedangkan objeknya adalah realitas yang ada di sekitarnya (Paulo Freire, 2007, p. 15). Dengan demikian, guru tidak lagi menempatkan anak didiknya seperti bejana kosong yang siap di isi, tetapi subjek aktip yang siap memecahkan permasalahan-permasalahan yang ada di sekitarnya.

Bagi Freire, pengharapan adalah kebutuhan ontologis. Keputusasaan tidak lain adalah pengharapan yang sudah kehilangan arah tujuannya, dan telah menjadi distorsi kebutuhan ontologis itu. Berpengharapan bukan karena sikap keras kepala, melainkan karena keharusan eksistensial kongkret. Maka, walaupun pemikiran Freire sering dikatakan sebagai pemikiran yang utopis, tapi Freire percaya bahwa utopis merupakan cita-cita yang mesti diwujudkan. Yaitu dengan menerapkan kesadaran magis, naif, hingga kritis pada masyarakat.

\section{Metode Penelitian}

Penelitian ini menggunakan pendekata komparatif. Komparatif adalah penelitian yang diawali dengan pengaruh variabel satu terhadap variabel lainnya, kemudian 
berusaha mencari kemungkinan variabel penyebab untuk menghubungkan maupun mempertentangkan (Prof. Sukardi, 2012, p. 171). Hal ini dimaksudkan untuk menemukan persamaan dan perbedaan antara beberapa objek yang diteliti, baik berupa ide-ide, gagasan, konsep dan sebagainya. Objek yang akan diteliti dalam penelitian ini adalah pemikiran Ahmad Tafsir dan Paulo Freire mengenai filsafat dan ilmu pendidikan.

Jenis Data penelitian ini adalah penelitian kepustakaan dengan menggunakan pendekatan kualitatif. Penelitian kepustakaan ini merupakan penelitian yang mengumpulkan data dan informasi dari berbagai macam materi yang terdapat dalam kepustakaan (Subagyo, 2001, p. 109). Dalam melakukan pengumpulan data, peneliti menggunakan metode analisis isi. Analisi isi adalah tehnik yang digunakan untuk menganalisis dan memahami teks, yang diuraikan secara objektif dan sistematis. Di sini penulis menguraikan pemikiran Ahmad Tafsir dan Paulo Freire yang mencakup: hakikat manusia; dasar pendidikan; tujuan pendidikan; dan metode belajar.

\section{Hasil dan Pembahasan}

\section{A. Pemikiran Ahmad Tafsir Mengenai Pendidikan Islam}

\section{Hakikat Manusia}

Menurut Ahmad Tafsir, penjelasan yang terbaik tentang hakikat manusia ialah penjelasan dari pencipta manusia itu, yakni Tuhan. Penjelasan oleh rasio manusia mempunyai kelemahan karena akal terbatas kemampuannya.

Ahmad Tafsir mengutip QS. Al-Qashash ayat 77 sebagai dasar argumen bahwa pada diri manusia mempunyai unsur jasmani (material). Unsur jasmani inilah yang tercipta dari segumpal tanah.

"Dan carilah pada apa yang telah dianugerahkan Allah kepadamu (kebahagiaan) negeri akhirat, dan janganlah kamu melupakan kebahagiaanmu dari (kenikmatan) duniawi. Dan berbuat baiklah (kepada orang lain) sebagaimana Allah telah berbuat baik kepadamu, dan janganlah kamu berbuat kerusakan di (muka) bumi. Sesungguhnya Allah tidak menyukai orang yang berbuat kerusakan." (QS. Al-Qashash: 77)

Selain itu dalam QS. Al-Araf ayat 31 juga dinyatakan bahwa manusia butuh makan dan minum. Bagi Ahmad Tafsir, itu satu indikasi bahwa manusia memiliki unsur jasmani.

"Hai anak Adam, pakailah pakaianmu yang indah disetiap (memasuki) mesjid, makan dan minumlan, dan janganlah berlebih-lebihan. Sesungguhnya Allah tidak menyukai orang-orang yang suka berlebih-lebihan." (QS. Al-Araaf: 31)

Selain aspek jasmani, manusia juga mempunyai aspek rohani. Penjelasan al-Quran tentang aspek ruhani salah satunya terdapat dalam QS. Al-Hijr ayat 29.

"Maka apabila Aku telah menyempurnakan kejadiannya, dan telah menuipkan ke dalamnya ruh (ciptaan)-Ku, maka tunduklah kamu kepadanya dengan bersujud.” (QS. Al-Hijr: 29)

Selanjutnya adalah aspek akal. Akal adalah alat untuk berpikir, maka menjadi hakikat manusia juga bila ia berpikir. Aspek akal sebagai hakikat manusia termaktub dalam QS. Az-Zumar ayat 9. 
"(Apakah kamu hai orang musyrik yang lebih beruntung) ataukah orang yang beribadat di waktu-waktu malam dengan sujud dan berdiri, sedang ia takut kepada (azab) akhirat dan mengharapkan rahmat Tuhannya? Katakanlah: Adakah sama orangorang yang mengetahui dengan orang-orang yang tidak mengetahui? Sesungguhnya orang yang berakallah yang dapat menerima pelajaran.” (QS. Az-Zumar: 9)

Selanjutnya Ahmad Tafsir pun mengutip ucapan Al-Syaibani dan Muhammad Qutb yang mengatakan bahwa hakikat manusia berdasarkan wahyu Tuhan adalah jasmani, rohani dan akal.

Dengan demikian, hakikat manusia adalah jasmani, rohani dan akal. Ketiga hakikat itulah yang mesti dijaga dan dikembangkan dalam pendidikan, dan harus seimbang. Karena kalau saja lemah salah satu unsurnya, maka manusia akan timpang.

\section{Dasar pendidikan}

Ahmad Tafsir membaca ada dua golongan dasar pendidikan. Pertama adalah rasionalisme dan yang kedua adalah filsafat negara yang ada muatan pesan-pesan Ilahiyah. Pendidikan yang mendasarkan pada rasionalisme yaitu yang mengatakan bahwa kebenaran diperoleh melalui akal dan diukur dengan akal. Maka, akal itulah sebagai pencari dan pengukur kebenaran (Ahmad, 2012, p. 10). Dengan kata lain, menurut aliran rasionalisme, akallah yang harus dijadikan dasar pendidikan.

Dengan begitu, maka kebenaran dalam dunia pendidikan bukanlah yang mesti dianut, atau pendidikan harus menghilangkan keseragaman. Karena toh setiap orang punya akal, maka setiap lembaga pendidikan pun berjalan sendiri-sendiri, sesuka kehendak akalnya.

Ahmad Tafsir mengungkapkan bahwa akal memang alat pencari kebenaran, tetapi bukan hanya akal, dan ada yang kedudukannya di atas akal. Karena kebenaran akal bisa ditumbangkan dengan akal lagi, tentu dunia pendidikan perlu kebenaran yang absolut, yang tak bisa ditumpaskan oleh akal, walau dalam waktu dan keadaan yang berbeda.

Maksudnya, nilai benar-salah merupakan kepanjangan tangan dari akal. Nilai baikburuk merupakan kepanjangan tangan dari ruhani. Dan nilai indah-tidak indah merupakan kepanjangan tangan dari jasmani. Maka semua harus berjalan secara seimbang, dan tak ada nilai yang lebih rendah bila didasarkan pada nilai ke-Ilahian.

\section{Tujuan Pendidikan}

Ada tiga garis besar yang dirumuskan Ahmad Tafsir mengenai tujuan pendidikan. Pertama adalah tujuan pendidikan secara falsafi. Kedua, tujuan pendidikan secara ilmu. Dan yang ketiga adalah tujuan pendidikan secara praksis.

Untuk menjawab rumusan masalah tersebut, maka tujuan pendidikan sudah masuk pada ranah ilmu. Ahmad Tafsir menyebutkan bahwa ada tiga ciri manusia terbaik menurut Islam, yaitu: Pertama, Jasmani yang sehat serta kuat dan berketerampilan. Kedua, akalnya cerdas serta pandai. Dan yang ketiga adalah ruhani yang berkualitas tinggi. Di sini terlihat kolerasi antara hakikat manusia, dasar pendidikan, hingga ke tujuan pendidikan menurut Ahmad Tafsir. 
Jasmani yang sehat serta kuat, sangat diperlukan untuk mengarungi kehidupan. Bukan hanya untuk kepentingan pribadi, tapi ada kalanya untuk membela ajaran Islam, karena dalam sejarahnya pun, umat muslim berjihad banyak menggunakan pisik dan mentalnya. Ahmad Tafsir pun menyebutkan bahwa mental adalah ajaran inti umat muslim.

Cerdas serta pandai, yaitu agar umat muslim tak hanya mampu menguasai teoriteori sains, tetapi berkemampuan pula menciptakan teori-teori baru dalam sains, termasuk teknologi. Selain itu, mempu memahami dan menghasilkan filsafat. Filsafat merupakan jenis pengetahuan yang semata-mata akliyah, dan umat muslim harus mampu memecahkan masalah filosofis.

Rohani yang berkualitas tinggi yang dimaksud Ahmad Tafsri adalah kalbu yang penuh berisi iman kepada Allah s.w.t, karena kalbu dapat menembus alam ghaib, bahkan menembus Tuhan. Kalbu yang iman itu ditandai bila orang mengerjakan salat, maka salatnya akan khusuk. Bila mengingat Allah s.w.t, maka hatinya akan tenang.

Dengan begitu, maka akan muncul manusia yang berpikir dan bertindak sesuai dengan kehendak Tuhan. Manusia yang hidup, tak lain akan kembali menghadap-Nya, maka sebaik-baiknya kehidupan yaitu yang digunakan untuk berjihad, berpikir dan bertindak di jalan-Nya.

\section{Metode Pendidikan}

Dalam KBBI, metode diartikan cara teratur yang digunakan untuk melaksanakan suatu pekerjaan agar tercapai sesuai dengan yang dikehendaki; atau, cara kerja yang bersistem untuk memudahkan pelaksanaan suatu kegiatan guna mencapai tujuan yang ditentukan.

Sedangkan metode pendidikan, Ahmad Tafsir mengartikannya sebagai semua cara yang digunakan dalam upaya mendidik. Kata metode diartikan lebih luas, karena mengajar adalah salah satu bentuk upaya mendidik. Maka metode yang dimaksud mencakup metode mengajar (Tafsir, 1992, p. 101)

Dalam literatur pendidikan Barat, terdapat beragam metode mengajar, seperti metode ceramah, tanya-jawab, diskusi, sosiodrama, bermain peran dan lain sebagainya. Bagi Ahmad Tafsir, metode-metode mengajar yang dikembangkan di Barat dapat saja digunakan atau diambil, untuk memperkaya teori tentang metode pedidikan Islam. Namun yang akan dibahas sekarang adalah metode yang berasaskan ajaran Islam, yaitu metode untuk menanamkan rasa iman.

Ahmad Tafsir mengutip pendapat al-Nahlawi, yang menerangkan ada tujuh metode, yaitu: metode hiwar (percakapan) Qurani dan Nabawi; metode kisah Qurani dan Nabawi; metode amtsal (perumpamaan) Qurani dan Nabawi; metode keteladanan; metode pembiasaan; metode 'ibrah dan mau'izah; dan metode targhib dan tarhib. Namun yang akan dibahas di sini hanya lima saja, mengingat ada persamaan atau dilakukan berbarengan dalam pelaksanaannya. 


\section{B. Pemikiran Paulo Freire Mengenai Pendidikan Kritis \\ 1. Hakikat manusia}

Paulo Freire merumuskan hakikat manusia menjadi dua bagian, yaitu: manusia sebagai mahluk yang bebas; dan manusia sebagai pencipta sejarah. Menurut pandangan Paulo Feire, kebebasan dalam aksiologisnya, selalu menjadi problema pokok manusia, dan kini persoalan itu harus dipedulikan. Kepedulian terhadap pemanusiaan seketika membawa pada pengakuan terhadap dehumanisasi, yang bukan hanya kemungkinan ontologis, melainkan sudah menjadi kenyataan historis.

Bagi Freire, masalah sentral manusia adalah humanisasi. Humanisasi merupakan sesuatu yang harus diperjuangkan, karena sejarah menunjukkan bahwa humanisasi dan dehumanisasi merupakan alternatif yang real. Akan tetapi, hanya humanisasi saja yang merupakan panggilan manusia yang sejati.

Dalam situasi itu, tampak kerinduan kaum tertindas akan kebebasan dan keinginan untuk merenggut kembali kemanusiaan yang hilang. Pembebasan yang sejati terjadi kalau tangan-tangan yang terangkat mengemis, diubah menjadi tangan-tangan manusiawi yang mampu mengubah dunia. Paulo Freire membagi manusia menjadi dua, yaitu kaum tertindas dan kaum penindas. Kaum tertindas adalah manusia yang tak bebas, sedang kaum penindas adalah manusia yang sudah kebablasan mengartikan kebebasannya.

Menurut Freire, kaum tertindas mampu memahami makna penindasan yang mengerikan, karena merekalah yang menanggung dan mengalami beban penindasan. Merekalah yang lebih bisa memahami keharusan pembebasan. Perjuangan pembebasan itu akan merupakan suatu tindakan cinta kasih melawan kebencian dan kemurahan hati palsu yang mewarnai kehidupan kaum penindas.

Paulo Freire mengembangkan konsep pendidikannya bertolak dari pandangannya tentang manusia dan dunia. Kodrat manusia menurut Freire, tidak saja berada dalam dunia, namun berada bersama dunia. Manusia tidak hanya hidup di dunia tetapi hidup dan berinteraksi dengan dunia. Situasi ini menunjukan bahwa manusia perlu orientasi untuk kehidupannya. Orientasi merupakan usaha pengembangan bahasa pikiran. Artinya bahwa manusia tidak hanya sanggup, namun juga mengerti dan untuk kemudian mengubah realitas (Murtiningsih, 2004, p. 7).

Maka Freire mengatakan bahwa tugas besar manusia bagi sejarah adalah membebaskan diri sendiri dan membebaskan para penindas. Untuk menaklukan situasi penindasan, manusia harus mengenali sebab-musababnya secara kritis, hingga ia dapat menciptakan situasi baru yang memungkinkan usaha mencapai keutuhan kemanusiaan. Meski situasi penindasan adalah situasi totalitas yang dehumanisasi dan mendehumanisasikan, yang mempengaruhi penindasan maupun yang ditindas. Kaum tertindaslah yang harus bangkit berjuang demi kemanusiaan yang lebih utuh.

\section{Humanisme Sebagai Dasar Pendidikan}

Paulo Freire mendasarkan pendidikannya pada humanisme. Bagi Freire, masyarakat terbagi atas golongan tertindas dan penindas. Oleh karenanya, pendidikan bagi kaum tertindas harusah dirancang sebagai perlawanan yang akan membebaskan 
mereka. Metodologi Freire dimaksudkan untuk mengolah bagaimana penindasan dapat berpartisipasi langsung dalam pendidikan.

Sebagai sebuah pendidikan yang berkemanusiaan dan memerdekakan, mempunyai dua tingkatan. Pertama, kaum tertindas membuka selubung dunia yang tertindas dan mereka sampai pada komitmen praksis untuk transformasi yang mengubah dunia. Kedua, pendidikan ini tidak hanya dimiliki oleh kaum tertindas, namun menjadi proses pendidikan bagi semua orang dalam perjuangan mewujudkan kemerdekaan secara permanen (Magnis-Suseno, 1995, pp. 61-62)

Semestinya pendidikan bukanlah wujud dari penindasan, melaikan mengantarkan peserta didik menjadi subjek. Diperlukan suatu lingkungan yang kondusif untuk mendukung di mana peserta didik dan pendidik secara bersama-sama menghadapi realitas. Artinya sebuah persoalan yang harus dilakukan bersama yang tidak bisa dilakukan secara terpisah.

Alasan utama mengapa Paulo Freire memiliki banyak pengikut adalah karena ia punya arah politik pendidikan yang jelas. Arah politik pendidikan Freire berporos pada keberpihakan kepada kaum tertindas. Kaum tertindas ini bisa diartikan bermacammacam. Tertindas oleh rezim otoiter, tertindas oleh struktur sosial yang tidak adil dan diskriminatif, tertindas karena warna kulit, gender, ras, dan lain sebagainya.

Setidaknya ada dua ciri orang tertindas: pertama, mereka mengalami alienasi dari diri dan lingkungannya. Mereka tidak bisa menjadi subjek otonom, tapi hanya mampu mengimitasi orang lain. Kedua, mereka merasa bodoh, tidak mengetahui apa-apa. Padahal ketika mereka berinteraksi dengan dunia dan manusia lain, maka sesungguhnya mereka tidak lagi menjadi bejana kosong, melainkan telah menjadi makhluk yang mengetahui (Nuryatno, 2011, p. 38)

\section{Tujuan Pendidikan}

Tujuan pendidikan Paulo Freire sangatlah umum, tidak hanya pada individu peserta didik, tetapi juga pada dunia yang ada disekelilingnya, maupun yang lebih luas. Maka tujuan pendidikan Paulo Freire dapat dibagi menjadi dua bagian, yaitu: individu yang mampu berkarya; dan perubahan sosial. Pendidikan bisa dikatakan berhasil, bagi Freire adalah ketika anak didik mampu mengungkap perasaan dan pikirannya. Pengungkapan perasaan dan pikiran sebagai rafleksi dari apa-apa yang sudah dicernanya melalui pendidikan, dan refleksi itu terbagi dalam beberpa medium, mau karya lewat kata, tulisan atau yang lainnya.

Berkarya seharusnya menjadi tujuan dalam setiap pendidikan, karena karya merupakan aksi nyata dari seseorang yang mempunyai hati dan pikiran. Selanjutnya Paulo Freire menjabarkan dalam bagan berikut:

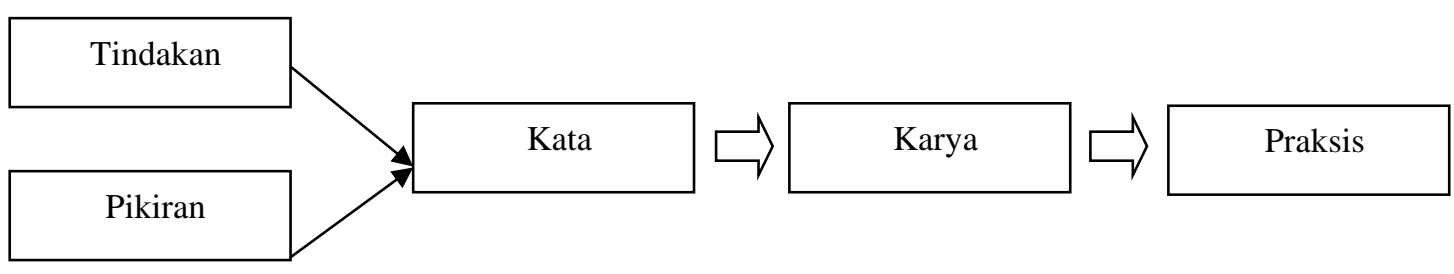


Walau tujuan masih teramat umum, karena karya dalam hal apa seseorang bisa dikatakan berhasil, tetapi justru karena itu Freire menginsafi keberagaman manusia yang punya bakat dan kemauan yang berbeda. Inti tujuan ini adalah agar manusi lepas dari ketertindasan dan ketakutan untuk mengungkap sesuatu, mau mengenai dirinya sendiri maupun dunia sekitarnya.

Bagi Freire, pendidikan haruslah berorientasi kepada pengenalan realitas diri manusia dan dirinya sendiri. Dengan begitu anak didik mampu mendiagnosa permasalahan-permasalahan apa saja yang bakal terjadi, dan siap menghadapinya.

Paulo Freire menyebutkan kalau unsur pendidikan adalah pendidik, anak didik dan realitas dunia. Itu tak lain supaya anak didik mampu mengatasi masalah-masalah yang sedang dihadapinya.

\section{Metode Pendidikan}

Paulo Freire menyodorkan dua metode pendidikan, yang sebenarnya keduanya bisa dilakukan dalam satu waktu yang berkesinambungan. Metode yang disodorkan Paulo Freire adalah metode dialog dan hadap-masalah.

Menurut Freire, hanya dialoglah yang menuntut adanya pemikiran kritis, yang mampu melahirkan pemikiran kritis. Tanpa dialog tidak akan ada komunikasi, dan tanpa komunikasi tidak akan mungkin adanya pendidikan sejati.

Dialog antar-manusia harus berdasarkan pada kepekaan terhadap kemampuankemampuan bawaan di dalam setiap manusia untuk menemukan diri sendiri. Dialog mengandaikan kerendahan hati, yaitu kemauan untuk belajar dari orang lain meskipun menurut perasaan dianggap lebih rendah. Dialog menuntut kepercayaan yang besar bahwa manusia pada hakikatnya dipanggil untuk menjadi subjek yang harus mengerjakan dan mengubah dunia (Collins, 2008, p. 2).

Selanjutnya Freire menyodorkan pendidikan metode hadap masalah sebagai dialog yang sesungguhnya. Pendidikan hadap masalah tidak membuat dikotomi kegiatan gurumurid. Murid tidak menyerap pada suatu saat dan menceritakan pada saat lain. Guru tidak menganggap objek-objek yang dapat dipahami sebagai milik pribadi, tetapi sebagai objek refleksi para murid serta dirinya sendiri. Dengan cara ini, pendidik secara terus-menerus memperbarui refleksi di dalam refleksi para murid. Guru menyajikan pelajaran kepada murid sebagai bahan pemikiran, dan menguji kembali pemikirannya yang terdahulu. Peran seorng pendidik hadap-masalah adalah menciptakan suasana di mana pengethuan tahap mantera diganti dengan pengetahuan sejati pada tahap ilmu (Ivan Illich, 1999, pp. 65-66).

Dalam pendidikan hadap-masalah, manusia mengembangkan kemampuan untuk memahami secara kritis, cara mereka mengada dalam dunia dengan mana dan dalam mana mereka menemukan diri sendiri. Mereka akan memandang dunia bukan sebagai realitas yang statis, tetapi sebagai realitas yang berada dalam proses, dalam gerak perubahan.

Meskipun hubungan dialektis antara manusia dan dunia berlangsung tanpa berkaitan dengan masalah bagaimana hubungan itu dipahami, namun benar juga bahwa 
bentuk tindakan yang dipilih manusia dalam bagian besar adalah suatu fungsi dari bagaimana mereka memandang diri sendiri dalam dunia.

Secara keseluruhan, perbedaan Ahmad Tafsir dan Paulo Freire terletak pada asumsi. Perbedaan mendasar lainnya karena Ahmad Tafsir dan Paulo Freire berada dalam lingkungan dan menghadapi konteks sosial yang jauh berbeda. Ahmad Tafsir mendasarkan pendidikanya pada kebenaran al-Quran, hadis dan akal; sedangkan Paulo Freire mendasarkan pendidikannya pada akal dan penglihatannya pada dunia (pengalaman). Perbedaan asumsi itulah yang melahirkan pemikiran-pemikiran yang berbeda dengan sangat mencolok, namun karena ada kesamaan saat menggunakan akal, maka terlahir pula persmaan-persamaannya, walau dengan tujuan dan praktik yang berbeda.

Karena persamaannya bisa dibilang sangat tipis, mungkin ada kesan "terlalu dipaksakan" saat mencari kesamaan. Term pendidikan Islam sebagai acuan Ahmad Tafsir dan term pendidikan Barat (lebih spesifiknya pendidikan kritis) sebagai acuan Paulo Freire, sudah mengindikasikan perbedaan yang amat mendasar.

Namun karena berhimpun atas nama pendidikan, maka kesamaan pun menjadi ada, dan tidak selalu diada-adakan. Karena sejauh ini, pendidikan dalam term apa pun, selalu memberi pengertian untuk kebaikan. Baik kebaikan di mata manusia maupun kebaikan di mata Tuhan. Minimalnya, kebaikan di mata manusia.

\section{a. Hakikat Manusia}

\section{- Persamaan}

Sebenarnya tidak ditemukan titik temu antarara pemikiran Ahmad Tafsir dan Paulo Freire saat berbicara soal hakikat manusia, karena Ahmad Tafsir berbicara manusia sebagai kata benda, sedangkan Paulo Freire berbicara manusia sebagai kata kerja.

Namun ketika berbicara manusia secara universal, maka terdapat kemiripan. Ahmad Tafsir menyebutnya dengan fitrah manusia, sedang Paulo Freire menyebutnya sebagai panggilan ontologis manusia. Maksudnya sama, bahwa dalam diri manusia terdapat nurani yang mengarahkan manusia pada kebaikan.

Namun konsep kebaikan yang dibawa oleh Ahmad Tafsir dan Paulo Freire berbeda. Jika Ahmad Tafsir melabuhkan kebaikannya kepada Tuhan, Paulo Freire melabuhkan kebaikannya pada humanisasi. Perbedaan, itu tak lepas dari konteks sosial yang mereka hadapi.

\section{- Perbedaan}

Perbedaan pemikiran antara Ahmad Tafsri dan Paulo Freire mengenai hakikat manusia sangat mencolok. Berawal dari pembahasan Ahmad Tafsir yang meletakkan manusia sebagai kata benda, sedang Paulo Freire meletakkanya sebagai kata kerja.

Menurut Ahmad Tafsir, manusia terdiri dari tiga unsur, yaitu jasmani, rohani dan akal. Ketiga unsur itulah yang kemudian dijadikan patokan oleh Ahmad Tafsir dalam merumuskan filsafat dan ilmu pendidikannya. Sedangkan menurut Paulo 
Freire, manusia dipandang dalam segi ontologi dan aksiologinya adalah sebagai mahluk yang bebas. Kebebasan menurut Freire mengarah pada humanisasi, dan menentang keras dehumanisasi. Humanisasi juga dijadikan patokan oleh Freire dalam merumuskan filsafat dan ilmu pendidikannya.

Selanjutnya mengenai kedudukan manusia. Bagi Ahmad Tafsir, kedudukan manusia itu adalah sebagai hamba Allah s.w.t. Sedangkan bagi Paulo Freire, kedudukan manusia itu adalah sebagai pencipta sejarah.

Konsep ketuhanan sangat lekat dengan pendapat-pendapat Ahmad Tafsir, karena baginya kebenaran yang mempunyai kedudukan tertinggi adalah kebenaran al-Quran, yang merupakan wahyu (petunjuk) dari Tuhan. Sedangkan pendapatpendapat Paulo Freire sangat terpaku pada akal dan penglihatannya tentang dunia.

Ahmad Tafsir lahir dan belajar dalam lingkungan yang sangat lekat keagamaannya, dan menghadapi gejolak realitas yang mulai terimingin oleh kehidupan modern.

Sedang Paulo Freire lahir dan belajar di lingkungan yang lekat dengan penindasan, kekuasaan yang disalah gunakan, dan pembodohan struktural. Ajaran kristiani tak memberi pencerahan baginya, maka ia berjalan dengan akal, nurani dan penglihatannya pada dunia.

\section{b. Dasar pendidikan}

\section{- Persamaan}

Saat Ahmad Tafsir berbicara mengenai konsep nilai dalam dasar pendidikannya, Paulo Freire berbicara kesadaran ontologis dalam dasar pendidikannya. Pembahasannya memang berbeda, karena Ahmad Tafsri berbicara tehnis, sedang Paulo Freire berbicara praksis, namun mengarah pada jalur yang sama.

Konsep nilai dan kesadaran ontologis mengarah pada pengetahuan benarsalah, baik-burut, dan indah-tak indah. Dalam kehidupan manusia ada normanorma yang harus ditaati, ada hukum moral dan etika yang harus dimengerti. Dan ada kalanya pengertian seseorang berbeda dengan yang lainnya, terlebih jika waktu dan keadaan yang berbeda. Namun ada pula hukum moral yang sama, seperti mencuri di belahan dunia manapun, tetap dianggap perbuatan yang tidak baik, terlepas yang ia curi itu memang hak-nya atau karena desakan.

Berangkat dari hukum moral yang samalah, seperti menolong orang lain adalah suatu kebaikan, dasar pendidikan Ahmad Tafsir dan Paulo Freire dari sisi itu bisa dikatakan sama.

\section{- $\quad$ Perbedaan}

Ahmad Tafsir meletakkan dasar pendidikannya pada filsafat negara, yang termuat juga konsep ketuhanan Yang Maha Esa. Dasar nilai benar-salah, baikburuk, indah-tak indah menjadi acuan di sisi lainnya. Ahmad Tafsir sangat mengecam keras rasionalisme yang melahirkan humanisme. 
Sedangkan Paulo Freire meletakkan dasar pendidikannya pada humanisme. Bagi Freire, humanisme dan dehumanisme merupakan alternatif yang real yang mesti dipilih salah satunya, dan Paulo Freire memilih humanisme.

Alasan Ahmad Tafsir menentang humanisme, karena manusia tak cukup mengatur segala kehidupan dengan menggunakan akal semata. Ada konsep yang lebih tinggi dalam mengatur kehidupan manusia, yakni Tuhan. Bagi Tafsir, humanisme adalah upaya untuk menafikan kekuasaan Tuhan akan kehidupan, dan manusia bertindak sebagai Tuhan sebagai pengatur dirinya maupun alam.

Paulo Freire memang tidak mengenalkan konsep ketuhanan dalam dasar pendidikannya, tidak pula menyuruh manusia bertindak sebagai Tuhan. Humanisme Freire adalah upaya untuk membebaskan manusia dari penjajah dominasi, kekuasaan, dan orang yang menganggap dirinya sebagai orang yang berpengetahuan, namun digunakan membodohi orang lain. Konsep ketuhanan Ahmad Tafsir adalah konsep kesadaran ontologis Paulo Freire.

Ahmad Tafsir memperkirakan, apa-apa yang dibangun oleh akal semata pada akhirnya akan hancur pula, semisal peradaban Barat. Penggunaan akal tanpa ada tuntunan, memang akan menyebabkan salah kaprah, atau kebebasan yang kebablasan. Namun Paulo Freire tidak meletakkan akal sebagai singgasana pemikirannya, tetapi lebih mendominankan nurani, yang dalam bahasa Freire-nya sebagai kesadaran ontologis manusia. Dari kesadaran nurani itulah Freire membangun konsep pendidikannya, yang oleh orang Barat pun dicibir sebagai pemikiran yang utopis.

Ketika Ahmad Tafsir melakukan "penyerangan" pada pemikiran pendidikan Barat, Paulo Freire pun melukan "penyerangan" pada dehumanisasi. Tentu ini tak lepas dari konteks sosial yang dihadapi oleh Ahmad Tafsir maupun Paulo Freire.

Konteks sosial yang dihadapi Ahmad Tafsir adalah menjalarnya pendidikan ala Barat, yang menghasilkan generasi-generasi intelektual namun cacat secara sosial. Pengadopsian pada pendidikan Barat hanya dalam segi angka-angka saja, yang tak dibarengi dengan pembenahan spiritual. Anak didik pun bisa dikatakan cerdas dalam soal matematika, fisika, kimia, namun tak menggubris soal moral dan akidah.

Maka Ahmad Tafsir muncul untuk mengatasi jamannya, mengembalikan pendidikan pada esensinya, yang memuat aspek jasmani, rohani dan akal. Ketiga aspek itu harus selaras dan berjalan beriringan, karena kalau tidak, akan timpang sebagai mana realitas yang dihadapi oleh Ahmad Tafsir.

Begitu pun Paulo Freire, kehidupan Brazilia pada tahun 1923 yang penuh dengan dominasi dan penindasan kaum lemah, menuntut Paulo Freire untuk bisa mengubah situasi itu. Pola pendidikan Paulo Freire pada waktu itu pun baru berpola pemberantasan buta huruf petani-petani. Lama-kelamaan Paulo Freire mengembangkan konsepnya itu dengan perlawanan pada kamu penindas, dan mencita-citakan humanisasi yang utuh pada diri manusia. 


\section{c. Tujuan pendidikan \\ - Persamaan}

Saat Ahmad Tafsir memberi penjelasan mengenai tujuan secara tehnik, sebagai penerapan filsafat dan ilmu tentang tujuan pendidikannya, Ahmad Tafsir mengatakan bahwa salah satu tujuan pendidikan adalah anak didik memiliki keterampilan.

Paulo Freire pun mengisyaratkan bahwa salah satu tujuan pendidikannya adalah anak didik mampu berkarya. Dengan mampu berkarya, bisa diartikan bahwa anak didik itu mempunyai keterampilan.

Di sisi lain, Ahmad Tafsir dan Paulo Freire mengisyaratkan bahwa tujuan pendidikan adalah dengan mampu menyelesaikan masalah-masalah yang dihadapinya di kehidupan nyata. Anak didik tak hanya cerdas berpikir, namun juga cerdas mengambil keputusan dan berbuat.

Dengan demikian, Ahmad Tafsir maupun Paulo Freire mempunyai pengertian bahwa pendidikan tak hanya bergulat dengan teori dan rumus-rumus, namun ada sisi yang harus diperhatikan dari kehidupan nyata. Dengan mempunyai karya atau keterampilan, anak didik diajarkan untuk tidak hanya mengemis-ngemis pada kehidupan, tapi mampu berkontribusi real.

Lebih jauh lagi, dalam tujuan pendidikan Ahmad Tafsir, yaitu diharapkan terciptanya masyarakat madani. Sedang Paulo Freire megharapkan perubahan sosial. Walau berbeda bahasa yang digunakan oleh Ahmad Tafsir dan Paulo Freire, namun keduanya mengarah pada kebaikan seluruh manusia, dan sebagai cita-cita yang luhur.

Dalam merumuskan tujuan pendidikan, Ahmad Tafsir dan Paulo Freire lebih terlihat kesamaannya ketimbang perbedaannya. Perbedaannya, Ahmad Tafsir mempunyai sisi yang lebih dalam bahasannya, dan konteks yang dibicarakannya.

\section{- Perbedaan}

Dari segi tujuan pendidikan sebagai anak yang mempunyai keterampilan, mampu menghadapi masalah yang sedang dihadapi, hingga terciptanya perubahan sosial, konsep Ahmad Tafsir dan Paulo Freire terlihat lebih banyak samanya. Namun tak lepas juga dari perbedaan.

Konsep Ahmad Tafsir ada lebihnya ketimbang Paulo Freire, karena salah satu tujuan pendidikan Ahmad Tafsir adalah hati yang takwa kepada Allah s.w.t. Nilai-nilai ketuhanan yang menjadi pembeda mendasar, karena Paulo Freire tidak menerapkan konsep ketuhanan dalam pendidikannya.

Perbedaan dasar itu pula, yang menjadikan konteks pembicaraan menjadi berbeda. Ahmad Tafsir tak hanya menjadikan kehidupan dunia saja yang menjadi akhir tujuan pendidikannya, namun juga menanamankan kehidupan yang lebih kekal, yakni akhirat.

Sedang Paulo Freire, mengukur segalanya dengan kehidupan dunia. Perjuangan dan pengorbanannya, untuk kebaikan manusia di dunia, sedang akhirat 
tak menjadi perhatiannya. Yang jelas baginya, penindasan harus segera dilenyapkan, keserakahan dan kerakusan harus segera dihentikan, dengan cara pendidikan yang menyikap dominasi dan kekuasaan politik.

Tujuan pendidikan Ahmad Tafsir lainnya adalah supaya menjadikan manusia taat beribadah, menjadi menusia sempurna bersama Yang Mahasempurna. Tentu, itu yang luput dari pengamatan Paulo Freire.

\section{d. Metode Pendidikan}

\section{- Persamaan}

Titik persamaan antara pemikiran Ahmad Tafsir dan Paulo Freire mengenai metode pendidikan adalah dalam dialog, atau dalam bahasa yang digunakan Ahmad Tafsirnya adalah hiwar.

Menurut Ahmad Tafsir, hiwar (dialog) ialah percakapan silih berganti antara dua pihak atau lebih mengenai suatu topik, dengan sengaja diarahkan kepada satu tujuan yang dikehendaki. Dalam percakapan itu, pembicaraan tidak dibatasi; dapat digunakan berbagai konsep sains, filsafat, seni, wahyu, dan lain-lain. Kadangkadang pembicaraan itu sampai pada satu kesimpulan, namun kadang-kadang pula tidak ada kesimpulan, karena salah satu pihak tidak puas terhadap pihak lain, tapi masing-masing mengambil pelajaran untuk menentukan sikap bagi dirinya.

Dan menurut Paulo Freire, hanya dialoglah yang menuntut adanya pemikiran kritis, yang mampu melahirkan pemikiran kritis. Tanpa dialog tidak akan ada komunikasi, dan tanpa komunikasi tidak akan mungkin adanya pendidikan sejati.

Dialog atau hiwar, akan merangsang anak didik untuk berpikir logis dan menggunakan dialektika. Selain diberi kesempatan untuk mengungkap apa yang ada di dalam pikiran anak didik, dengan dialog juga mengajarkan pada anak didik untuk menghargai pendapat orang lain yang menjadi lawan bicaranya.

\section{- Perbedaan}

Perbedaan metode pendidikan Ahmad Tafsir dan Paulo Freire lebih pada aspek materi, atau yang hendak dicapai dengan menggunakan metode tersebut.

Jika Ahmad Tafsir menginginkan agar anak didiknya lebih meresapi kelangsungan keimanannya kepada Allah s.w.t, sedangkan Paulo Freire lebih kepada kesadaran anak didiknya di mata dunia. Dengan begitu, jelas yang dimaksud isi dialog dalam metode Ahmad Tafsir adalah tak lepas dari kajian-kajian keislaman, sedangkan ini dialog dalam metode Paulo Freire adalah masalahmasalah yang sedang dihadapi dalam realitas kehidupan.

Perbedaan lainnya terletak pada metode perumpamaan, keteladanan dan pembiasaan yang dibahas oleh Ahmad Tafsir, namun tidak menjadi perhatian bagi Paulo Freire. Dan metode hadap-masalah dalam pembahasan Paulo Freire, namun tak dibahas oleh Ahmad Tafsir.

\section{Kesimpulan}


Persamaan antara pemikiran Ahmad Tafsir dan Paulo Freire yang paling mencolok adalah pada metode dialog, atau bahasa Ahmad Tafsirnya adalah hiwar. Keduanya meyakini bahwa dengan cara dialog, mampu merangsang anak untuk berpikir logis, serta menggunakan dialektikanya. Persamaan lainnya terdapat pada tujuan pendidikan, yaitu supaya anak mempunyai keterampilan dan mampu mengatasi masalahmasalah yang dihadapinya, dengan pertimbangan-pertimbangan yang logis dan filosofis. Satu indikasi bahwa pendidikan tak hanya belajar angka dan teori, tapi juga belajar tentang kehidupan.

Sedangkan perbedaannya terletak pada asumsi. Ahmad Tafsri menempatkan kebenaran wahyu sebagai yang paling utama, seterusnya adalah hadis, lalu akal. Sedangkan Paulo Freire menempatkan akal dan pengalaman sebegai otoritas kebenaran. Perbedaan asumsi itu terus menjalar pada perbedaan hakikat manusia, dasar pendidikan, tujuan pendidikan, hingga ke metode pendidikan. Yang melatar-belakangi perbedaan asumsi itu adalah perbedaan lingkungan dan konteks sosial yang mereka hadapi. 


\section{BIBLIOGRAFI}

Ahmad, T. (2012). Filsafat Pendidikan Islam (Integrasi Jasmani, Rohani dan Kalbu Memanusiakan Manusia). Bandung: Remaja Rosdakarya.

Collins, D. E. (2008). Paulo Freire: Kehidupan, Karya, dan Pemikiran. Yogyakarta: Pustaka Pelajar.

Freire, P. (2018). Pedagogy of the oppressed. Bloomsbury publishing USA.

Ivan Illich, P. F. dkk. (1999). Menggugat Pendidikan, Fundamentalis, Konservatif, Liberal, Anarkis. (1st ed.). Yogjakatra: Yogjakatra: Pustaka Pelajar.

Magnis-Suseno, F. (1995). Filsafat sebagai ilmu kritis (3rd ed.). Penerbit PT Kanisius.

Murtiningsih, S. (2004). Pendidikan Alat Perlawanan: Teori Pendidikan Radikal Paulo Freire. Resist Book.

Nuryatno, M. A. (2011). Mazhab pendidikan kritis: menyingkap relasi pengetahuan, politik, dan kekuasaan. Resist Book.

Paulo Freire, P. F. (2007). Politik Pendidikan: Kebudayaan, kekuasaan dan pembebasan. Pustaka Pelajar.

Prof. Sukardi, P. D. (2012). Metodologi Penelitian Pendidikan (11th ed.). Jakarta: Jakarta: Bumi Aksara.

Subagyo, P. J. (2001). Metode Penelitian Teori dan Praktek. In Jakarta. Rineka Cipta (1st ed.).

Tafsir, A. (1992). Ilmu pendidikan dalam perspektif Islam. Remaja Rosdakarya. 